\title{
SUBSTANTIATION OF CONSTRUCTIVE PARAMETERS OF A FRAME STRUCTURE ELEMENTS OF THE ROPE MECHANISM TRANSPORT SYSTEM FOR STORING PIECE LOADINGS INTO SMALL WAREHOUSES
}

\author{
Roman Hevko; Yurii Nykerui; Taras Dovbush; Vasyl Oleksyuk
}

\author{
Ternopil Ivan Puluj National Technical University, Ternopil, Ukraine
}

\begin{abstract}
Summary. The article provides a theoretical substantiation of the structural parameters of the frame structure for the placement of piece loads, as well as clamping levers with rollers and their arrangement, which interact with the inner surface of the guide ropes of the developed transport system. The established limits of rational parameters and angular positions of levers and their compression springs to the inclined sidewalls for the right and left sides of the movable elements of the frame structure relative to the central vertical axis, as well as the angle of the guide ropes to the horizon. On the basis of the results of calculations and recommendations for the choice of parameters of the proposed technical solutions, a rope mechanism for storing piece loadings into small warehouses was manufactured and preliminary experimental studies were carried out.
\end{abstract}

Key words: rope mechanism, design parameters, clamping levers, support rollers, turning angles.

https://doi.org/10.33108/visnyk_tntu2020.04.062

Received 23.10.2020

Statement of the problem. Technological processes of loading piece loads, such as apples, potatoes or other fruit and vegetables, into warehouses need to meet the demands to their quality, especially for them to remain intact when it concerns the process of their storing to the unloading area as there should not be any damages at all or they have not exceed the permissible standards.

Analysis of resent researches. Analysis of investigation of processes of loading piece loads into storage rooms by various types of transporting-technological machinery is presented in studies [1-6]. However, the traditional types of transporting mechanisms are rather complex structurally and material-demanding, and their use is economically feasible when transporting loads over long distances.

Known rope transporting mechanisms for moving various piece loads, can be prototypes in the development of new transport and technological machinery, as presented in articles [7-11].

The developed experimental devices and the research methods together with the results of previous studies of the proposed rope transporting and technological mechanism are given in the articles $[12,13]$.

Objectives of the research. To substantiate the structural parameters and mutual locations of elastically connected elements of the frame structure of the rope mechanism transporting system for moving piece loads which would provide their maximum rapid transportation avoiding sharp oscillations to prevent damaging the transported loads.

Setting of the problem. Detrmine the limits of rational design parameters and angular position of transporting system of the rope mechanism.

Results of the research. For soring piece loads into warehouses the transportation system is developed which bases on the pair of parallel ropes fixed to the opposite walls of the warehouse and movable triangular frame structure with pressing levers; the principle of its work and also its elements are described in detail in the patents of Ukraine for useful models [14-15]. 
General view of the rope mechanism and triangular frame structure for storing loads with compressed springs levers and rollers is presented in Fig. 1. Accurate description of its construction and principles of operation are given in articles $[14,15]$.

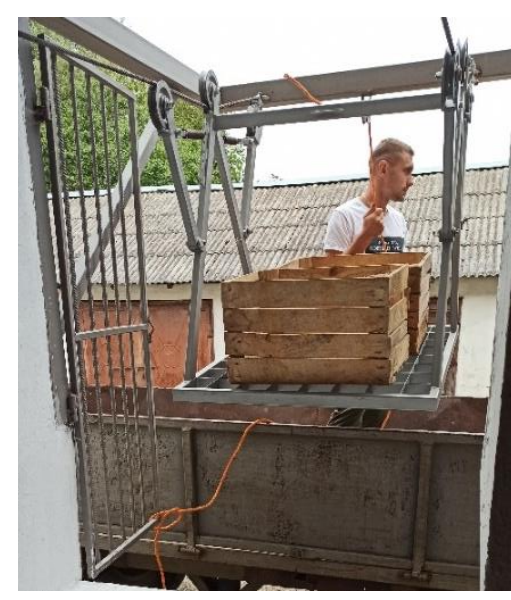

a)

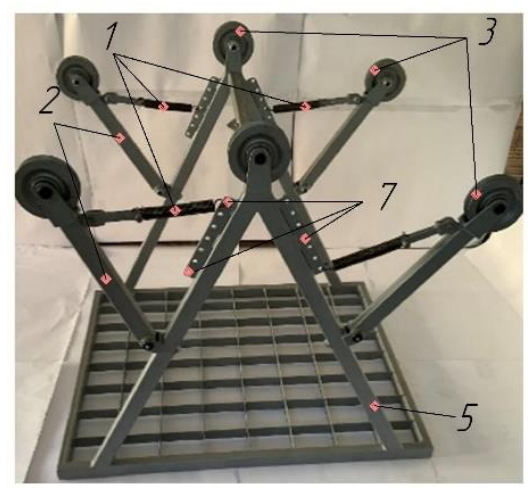

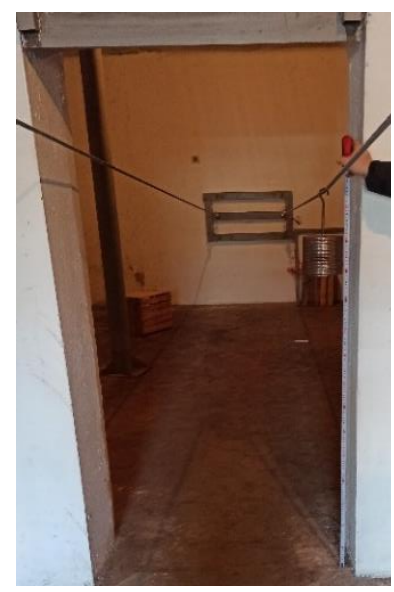

b)

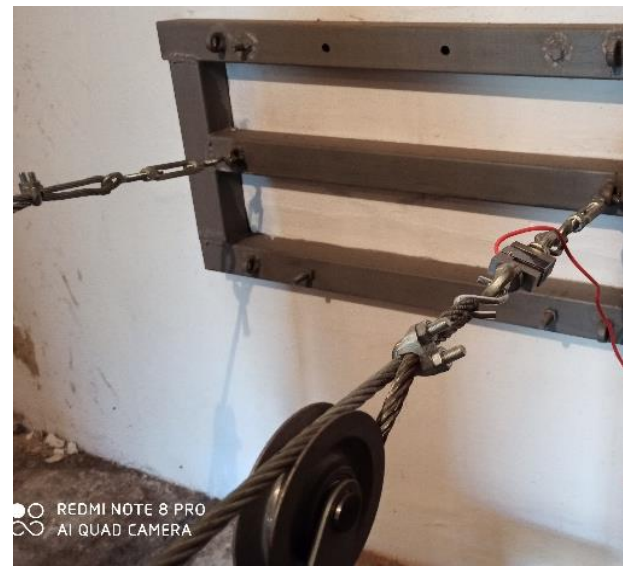

c)
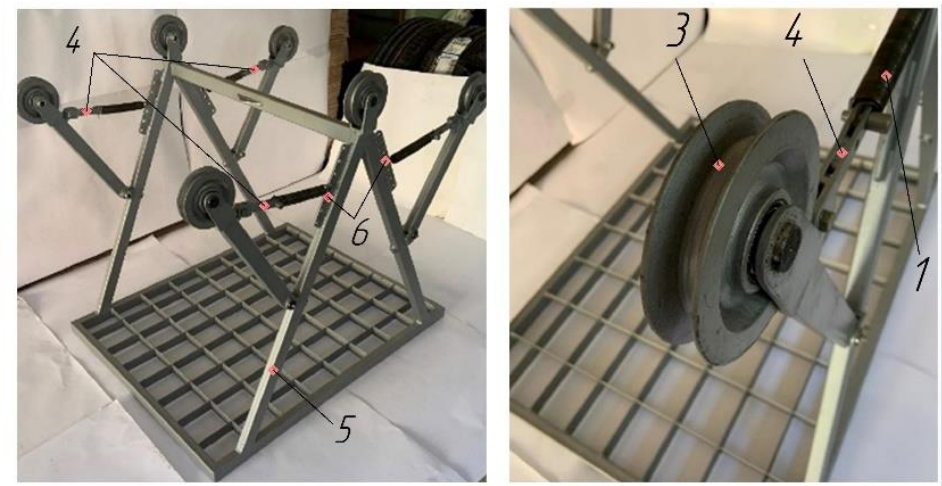

d)

Figure 1. General view of the rope mechanism and triangular frame construction for the location of loads with compressed springs levers and rollers: $\mathrm{a}$ - loading area of piece loads; $\mathrm{b}$-pair of ropes that are located at an angle to the horizon; $\mathrm{c}$ - fastening of ropes to the inner wall of the warehouse in the area of unloading of piece goods; $\mathrm{d}$ - frame structure for the location of piece cargo: 1 - springs; 2 - levers; 3 - rollers; 4 - thrust; 5 - sides of the frame structure; 6 - flat plates; 7 - hole

Calculation scheme for setting design parameters in contact of a triangular frame structure with tension levers and rollers and guide ropes is shown in Figure 2.

On the scheme, on plane $O X Y$ the central rollers 1 are shown, a pair of which is installed at a certain distance in relation to central axis $O$ and are leaned on stretched ropes 2. Ropes are located at the angle $\alpha$ to the horizon.

With the central axis $O$ the triangular frame structure with sides 3 for placement of piece loads 4 in container is hinged. To the sides, the levers 5 with pressure rollers 6 which interact with the inner surface of the ropes 2 are hinged. 


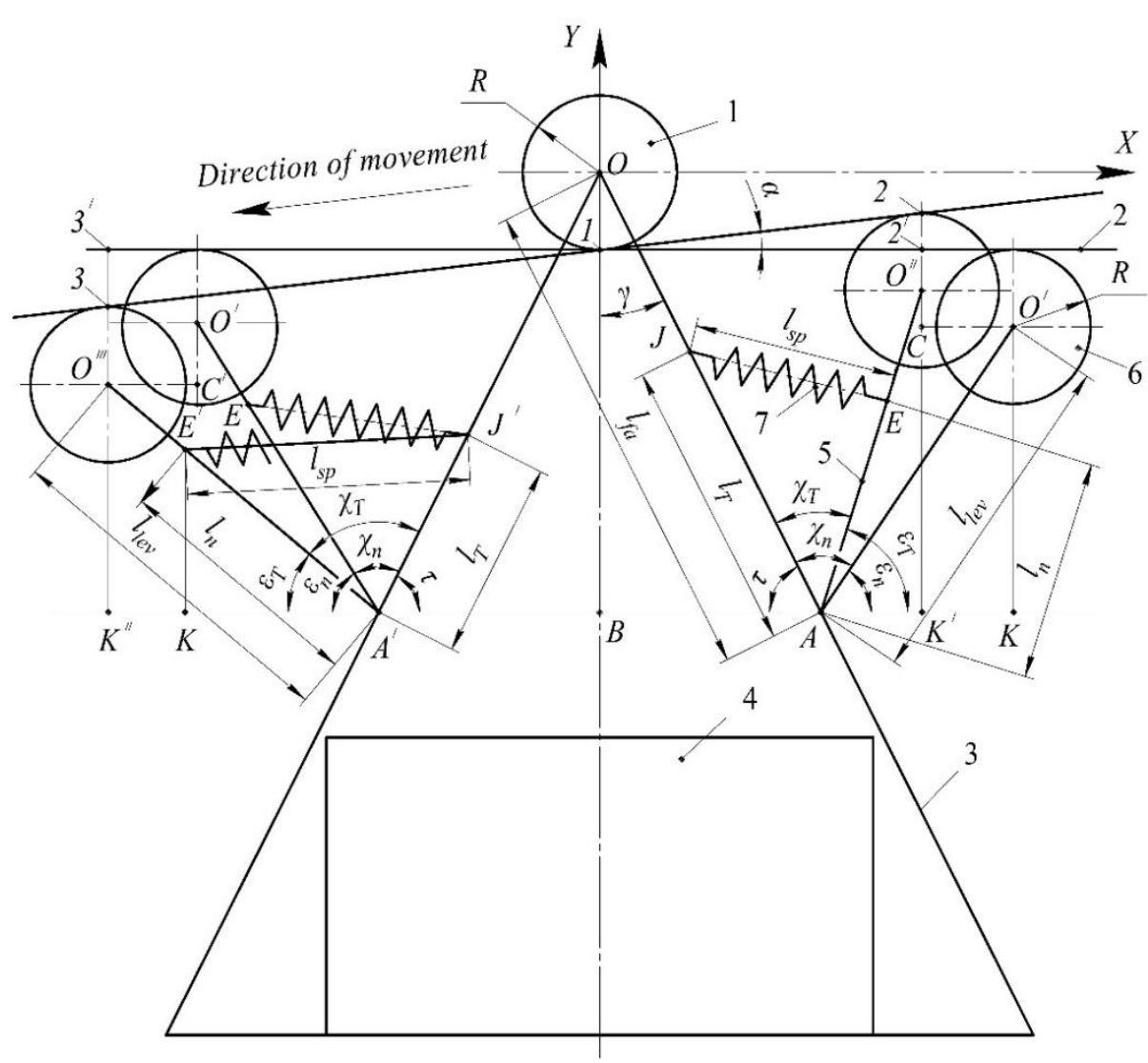

Figure 2. Calculation scheme for setting design parameters in contact of a triangular frame structure with tension levers and rollers and guide ropes

The levers are spring-loaded towards the sides of the frame structure with compression springs 7 (of the same or different length and stiffness), and the point of their attachment to the sides may vary.

As previous studies have shown, the length of the compression spring should be chosen so that in the initial state to minimize the roll-compression 6 of the inner surface of the ropes. This will make it possible to avoid the braking of the frame structure with the loads in the process of their motion.

The compression springs have to dampen out the probable oscillations of the frame structure in relation to rolls 1 (mostly in unloading area where the abrupt braking of the system occurs).

First, consider the placement of the levers with rolls from the right to the axis $O Y$, i.e. from the opposite side to the direction of the frame structure motion.

During the studying, the following assumption has been made: the rope tension force is sufficient for conventional taking its area between the central and compression rolls as a straight line.

Previously, determine the initial value of the angle $\chi_{n}$ between the line of lever with the length $l_{l e v}$ placement relative to the sides of the frame structure located at angle $\gamma$ to axis $O Y$. Herewith, the ropes are placed horizontally and respectively, the angle $\alpha$ of their placement to horizon is equal $0: \alpha=0^{\circ}$.

As the geometric parameters of the triangular frame structure for each individual case are unchangeable, we previously determine the distance from the rotation axis of the supportive rolls p. $O$ to p. $B$ which defines the horizontal position of the levers hinging (p. $A$ ) to the sides of triangular frame structure: $O B$ 


$$
O B=l_{f a} \cos \gamma
$$

where $l_{f a}$ is the distance from axis of rotation of supporting rollers p. $O$ to p. $A$ of hinging the levers to the sides of triangular frame structure.

Then determine the distance from the center of compression rollers p. $O^{\prime}$ during their contact with conditionally horizontally placed ropes $\left(\alpha=0^{\circ}\right)$ to p. $K$ located on the joining line of hinging points of levers (p. $A$ and p. $A^{\prime}$ ) to the sides of triangular frame structure: $O^{\prime} K$

$$
O^{\prime} K=O B-2 R=l_{f a} \cos \gamma-2 R,
$$

where $R$ is the radius of rollers.

Then the initial angle $\varepsilon_{n}$, which determines the lever position, when $\alpha=0^{\circ}$ to horizon, is calculated from the dependence

$$
\begin{aligned}
& \sin \varepsilon_{n}=O^{\prime} K / l_{l e v}=\left(l_{f a} \cos \gamma-2 R\right) / l_{l e v} \\
& \varepsilon_{n}=\arcsin \left(\left[l_{f a} \cos \gamma-2 R\right] / l_{l e v}\right)
\end{aligned}
$$

For the analysis of functional dependence $\varepsilon_{n}=f\left(l_{f a}\right)$, the respective graphic dependences are drawn (Fig. 3) at different values of angle $\gamma: \gamma=23,6^{\circ}(B A=200 \mathrm{~mm}) ; \gamma=26,1^{\circ}$ $(B A=220 \mathrm{~mm}) ; \quad \gamma=28,7^{\circ} \quad(B A=240 \mathrm{~mm}) ; \quad \gamma=31,3^{\circ} \quad(B A=260 \mathrm{~mm}) ; \quad \gamma=34,1^{\circ}$ $(B A=280 \mathrm{~mm})$. Herewith, the following structural parameters remained unchanged: $R=45 \mathrm{~mm} ; l_{l e v}=400 \mathrm{~mm}$.

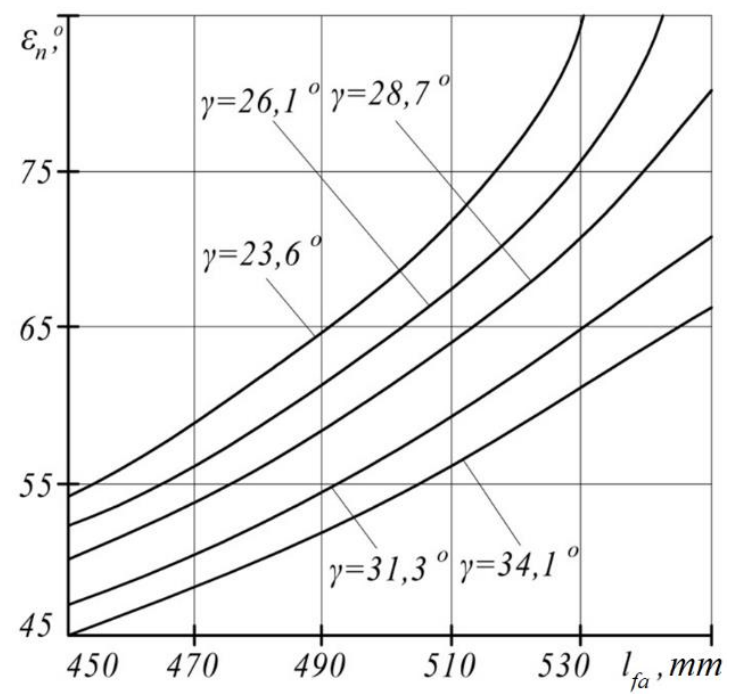

Figure 3. Graphical dependences $\varepsilon_{n}=f\left(l_{f a}\right)$ at different values of the angle $\gamma$

Analysis of graphical dependences (Fig. 3) has shown that with stable value of radius $\mathrm{R}$ of compressive rollers and the levers length $l_{l e v}$, decrease of angle $\gamma$ from $23.6^{\circ}$ to $34.1^{\circ}$, as well as the extension of the distance $l_{f a}$ causes the significant increase of the initial value of angle $\varepsilon_{n}$.

For above mentioned values $R$ and $l_{l e v}$, the increase of distance $l_{f a} \geq 530 \mathrm{~mm}$ does not ensure the contact of rollers with the ropes in vertical position which levels up the designated allocation of roller levers.

Thus, the following variable constructive parameters should be recommended: $l_{f a}=450 \ldots 525 \mathrm{~mm}$ and $\gamma=26^{\circ} \ldots 34^{\circ}$ that correspond the maximum range of calculation values 
$\varepsilon_{n}=45^{\circ} \ldots 75^{\circ}$. The increase of the value of angle $\gamma$ also contributes the extension of the area of triangular frame structure basis where containers with piece load are placed.

After that, we find the functional dependence $\chi_{n}=f\left(l_{f a}\right)$.

From the right-angled triangle $\triangle O B A$ the inclination angle $\tau$ of the sides of triangular frame structure to the horizon is determined: $\tau=90^{\circ}-\gamma$.

Then the initial angle $\chi_{n}$ is calculated from the equation

$$
\begin{gathered}
\chi_{n}=180^{\circ}-\tau-\varepsilon_{n}=360^{\circ}-\left(90^{\circ}-\gamma\right)-\arcsin \left(\left[l_{f a} \cos \gamma-2 R\right] / l_{l e v}\right) ; \\
\chi_{n}=90^{\circ}+\gamma-\arcsin \left(\left[l_{f a} \cos \gamma-2 R\right] / l_{l e v}\right) .
\end{gathered}
$$

To analyze the influence of functionally joined together parameters $\gamma$ and $l_{f a}$ on the angle $\chi_{n}$ when the values $R=45 \mathrm{~mm}$ and $l_{\text {lev }}=400 \mathrm{~mm}$ are unvaried, the graphical dependences $\chi_{n}=f\left(l_{f a}\right)$ with the angle values $\gamma=26^{\circ} \ldots 34^{\circ}$ are drawn, which are presented in Fig. 4.

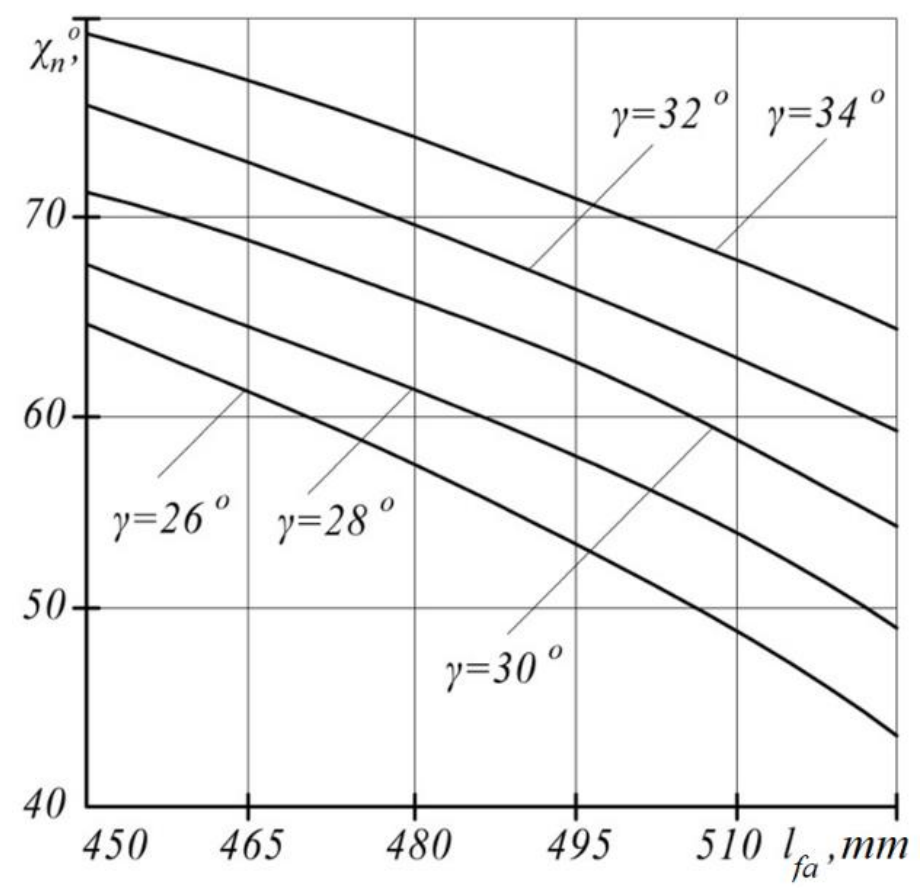

Figure 4. Graphical dependences $\chi_{n}=f\left(l_{f a}\right)$ at angle values $\gamma=26^{\circ}, 28^{\circ}, 30^{\circ}, 30^{\circ}, 34^{\circ}$

According to the previous research (Fig. 3) and recommendations on selection of the structural materials, value $l_{f a}$ varies within $l_{f a}=450 \ldots .525 \mathrm{~mm}$ and the angle varies within $\gamma=26^{\circ} \ldots 34^{\circ}$ that corresponds the change of the angle bounds $\varepsilon_{n}=45^{\circ} \ldots 75^{\circ}$.

Analysis of graphical dependences has shown that they are slightly convex, and increase of angle $\gamma$ brings to increase in the initial angle $\chi_{n}$.

Increasing the value of the hinged attachment of the levers to the sides of the frame $l_{f a}$ in the range from 450 to $525 \mathrm{~mm}$ causes decrease in the value of the angle $\chi_{n}$ by: $32,2 \%$ for $\gamma=26^{\circ} ; 27,9 \%$ for $\gamma=28^{\circ} ; 24 \%$ for $\gamma=30^{\circ} ; 21 \%$ for $\gamma=32^{\circ} ; 18,6 \%$ for $\gamma=34^{\circ}$.

The next stage in theoretical research is to establish the relationship between the flow angles $\varepsilon_{T}, \chi_{T}$ and the angle $\alpha$ of the location of the ropes to the horizon. The values of the angles $\varepsilon_{T}$ and $\chi_{T}$ vary in the range from their initial values $\left(\varepsilon_{n}\right.$ and $\left.\chi_{n}\right)$ to the maximum possible value at which the pressure rollers contact with the ropes with increasing value of the angle $\alpha$. 
For small angular rotations of the pressure rollers, in their upper part and small radii $R \leq$ $50 \mathrm{~mm}$, around the ropes, as well as to simplify the derived analytical dependences for their practical use, we assume that at a small angle $\alpha$ location of ropes to the horizon they contact with the pressure rollers at points 1 and 2 respectively.

As the previous calculations have shown, as well as real bending of ropes around the rollers [10], such supposition may be applied for further theoretical analysis, as it does not significantly affect the obtained values of the desired measurements.

Giving the values step by step $\varepsilon_{T}>\varepsilon_{n}$, dependence for determining the value $O^{\prime \prime} K^{\prime}$ as a function of angle $\varepsilon_{T}$ will be as follows

$$
\begin{gathered}
\sin \varepsilon_{T}=O^{\prime \prime} K^{\prime} / l_{l e v} \\
O^{\prime \prime} K^{\prime}=l_{l e v} \sin \varepsilon_{T} .
\end{gathered}
$$

We previously derive the dependence for calculating the distance $O^{\prime \prime} C$

$$
O^{\prime \prime} C=O^{\prime \prime} K^{\prime \prime}-O^{\prime} K=l_{l e v} \sin \varepsilon_{T}-\left(l_{f a} \cos \gamma-2 R\right) \text {. }
$$

From the calculation scheme it is evident that distance $O^{\prime \prime} C$ is equal to distance $22^{\prime}$ : $O^{\prime \prime} C=22^{\prime}$. Then

$$
\operatorname{tg} \alpha=22^{\prime} / B K^{\prime}
$$

Value $B K^{\prime}$ is determined

$$
B K^{\prime}=B A+A K^{\prime}=l_{f a} \sin \gamma+l_{l e v} \cos \varepsilon_{T} .
$$

Substituting (6) and (8) into equation (7), we obtain

$$
\begin{array}{r}
\operatorname{tg} \alpha=\left(l_{l e v} \sin \varepsilon_{T}-l_{f a} \cos \gamma+2 R\right) /\left(l_{f a} \sin \gamma+l_{l e v} \cos \varepsilon_{T}\right), \\
\alpha=\operatorname{arctg}\left[\left(l_{l e v} \sin \varepsilon_{T}-l_{f a} \cos \gamma+2 R\right) /\left(l_{f a} \sin \gamma+l_{l e v} \cos \varepsilon_{T}\right)\right] .
\end{array}
$$

While analyzing the dependence (9), we will use the recommended range of the parameters values, which were previously found (Fig. 3 and 4).

Also, when establishing the functional dependence $\alpha=f\left(\varepsilon_{T}\right)$, first, according to formula 3 , we determine the relationship between the values of $\varepsilon_{n}$ and $l_{f a}$ for the recommended values of the angle $\gamma$.

Having found the value $\varepsilon_{n}$ for specific values of $l_{f a}$ and $\gamma$ for $R$ and $l_{l e v}=$ const further, step by step, given the value of the angle $\varepsilon_{T}>\varepsilon_{n}$ by formula (9), the value of the angle $\alpha$ is calculated.

Figure 5 shows the graphical dependences $\alpha=f\left(\varepsilon_{T}\right)$ for $\gamma=26^{\circ}, 34^{\circ}$.

From the analysis of the diagramed graphic dependences, it is possible to state that growth of absolute values of interconnected parameters $\varepsilon_{n}$ and $l_{f a}$ causes both the reduction of change range of an inclination angle of ropes $\alpha$ to horizon, and decrease in its absolute maximum value.

Analysis of the diagramed graphical dependences showed that the change in the value of the angle $\gamma$ does not affect the nature of their change, but the increase in the angle $\gamma$ from $26^{\circ}$ to $34^{\circ}$ causes the increase in the value of $\alpha_{\max }$ by 1.11 times, which is insignificant. 


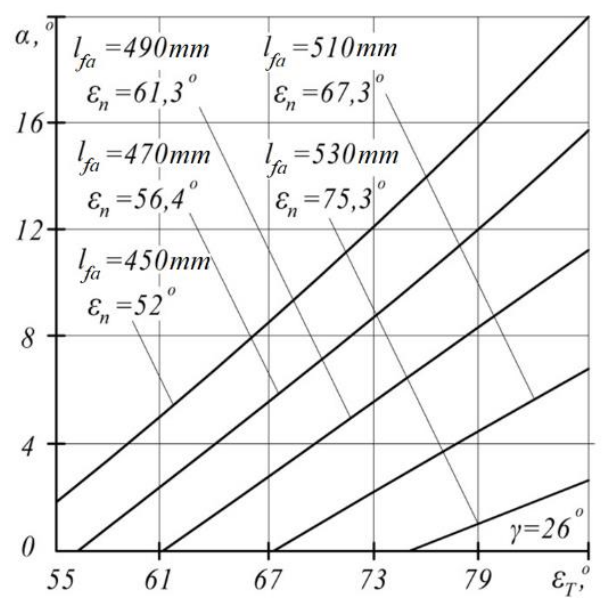

a)

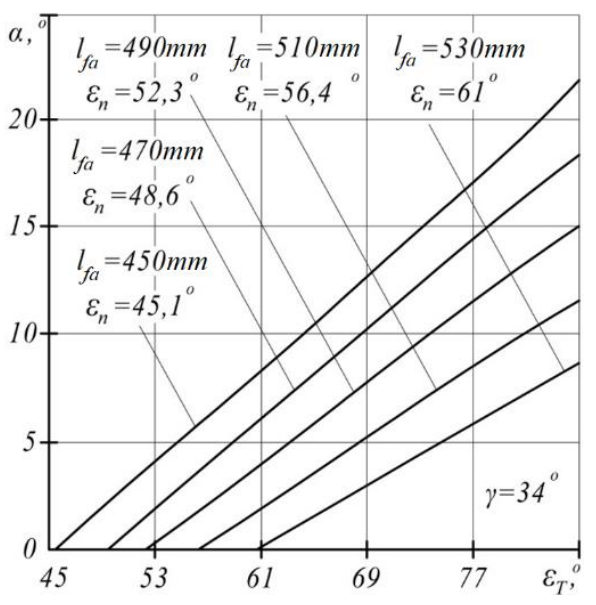

b)

Figure 5. Graphic dependences $\alpha=f\left(\varepsilon_{T}\right)$ at different values of the angle $\varepsilon_{n}$, values of $l_{f a}$, for: $\mathrm{a}-\gamma=26^{\circ} ; \mathrm{b}-\gamma=34^{\circ}$

In this case, when changing $\gamma$ from $26^{\circ}$ to $34^{\circ}$, for the maximum values of $\varepsilon_{T}$ and $l_{f a}$, the range of change $\alpha$ increases from $2,7^{\circ}$ to $8,5^{\circ}$, i.e. by 3.15 .

Thus, choosing rational parameters, it is necessary to consider the position of compression spring of the lever in the direction of an inclined side of a frame structure and accordingly a direction of action of spring force. For big values of $\varepsilon_{n}$ and $l_{f a}$, the component of this force will be much larger in the direction of rotation of the lever, and therefore there can be chosen less stiffness of the spring, which will improve maintenance and repair.

The next stage is to determine the influence of the design parameters of the rope mechanism and its elements, as well as different areas of attachment of compression springs to their initial length when the rollers come into contact with the ropes, which are located at different angles $\alpha$ to the horizon.

To ensure the action of the minimum force of the spring on the roller lever, which is provided by a slight pre-tension in the initial loading state of the frame structure, the transporting system structurally provides for adjusting the position of the tension springs. Therefore, flat plates 6 with a number of holes 7 (Figure 1) for attaching springs are welded to the inclined sides of the frame.

In the area of joining springs 1 to the levers 2 , it is also possible to provide mechanical adjustment of their length by means of rods 4 with locking pins 7 , which can be located in different positions in the holes of the rods, as shown in Figure 6.

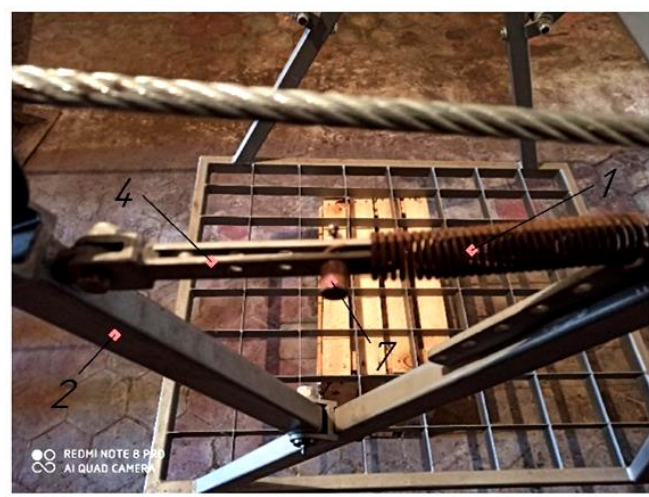

a)

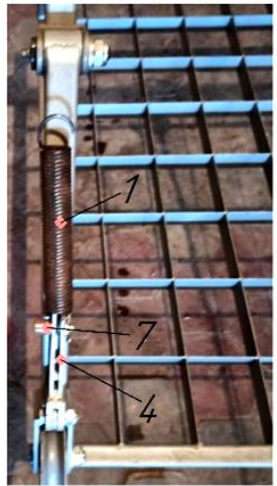

b)

Figure 6. General view of mechanical adjustment of fixation of tension springs of different length 
Firstly, we determine the length of spring $l_{s p}$ in the initial state of the loaded frame structure depending on the distance $l_{T}$ (distance from point $A$ of the lever hinged to the side of the frame structure to the point $J$ of joining the compressive spring to it) and distance $l_{n}$ (distance from point $A$ of the lever hinging to the side of the frame structure to point $E$ of joining to the lever of compressive spring).

To do this, we use the cosine theorem

$$
l_{s p}^{2}=l_{T}^{2}+l_{n}^{2}-l_{T} \cdot l_{n} \cdot \cos \chi_{T}
$$

Current angle $\chi_{T}$ is determined

$$
\begin{gathered}
\chi_{T}=180^{\circ}-\tau-\varepsilon_{T} ; \quad \tau=90^{\circ}-\gamma ; \\
\chi_{T}=180^{\circ}-90^{\circ}+\gamma-\varepsilon_{T} ; \\
\chi_{T}=90^{\circ}+\gamma-\varepsilon_{T} .
\end{gathered}
$$

Substituting (11) into (10), we obtain

$$
\begin{aligned}
& l_{s p}^{2}=l_{T}^{2}+l_{n}^{2}-l_{T} \cdot l_{n} \cdot \cos \left(90^{\circ}+\gamma-\varepsilon_{T}\right) ; \\
& l_{s p}=\left[l_{T}^{2}+l_{n}^{2}-l_{T} \cdot l_{n} \cdot \sin \left(\varepsilon_{T}-\gamma\right)\right]^{0,5} .
\end{aligned}
$$

While analyzing dependences (12), it is appropriate to set the range of discrete values to $l_{T}$ and $l_{n}$ according to the previous research, namely $l_{T}=(220 ; 250 ; 280 ; 310 ; 340 ; 370$; 400) $\mathrm{mm} ; l_{n}=(280 ; 300 ; 320) \mathrm{mm}$.

Values of angles $\gamma$ and $\varepsilon_{T}$ are given within the range given in the graphical dependences (Fig. 5). Therefore, angle $\gamma$ takes the values $\gamma=26^{\circ} ; 30^{\circ} ; 34^{\circ}$, and angle $\varepsilon_{T}=45 \ldots 85^{\circ}$.

Herewith, according to calculations for angle $\gamma=26^{\circ}$, angle $\varepsilon_{T}$ changes within $\varepsilon_{T}=45 \ldots 85^{\circ}$; for angle $\gamma=30^{\circ}$ within $\varepsilon_{T}=50 \ldots 85^{\circ}$; for angle $\gamma=34^{\circ}$ within $\varepsilon_{T}=55 \ldots 85^{\circ}$.

In Figure 7, the graphical dependences $l_{s p}=f\left(\varepsilon_{T}\right)$ for different values of angle $\gamma$ and $l_{T}$ are presented.

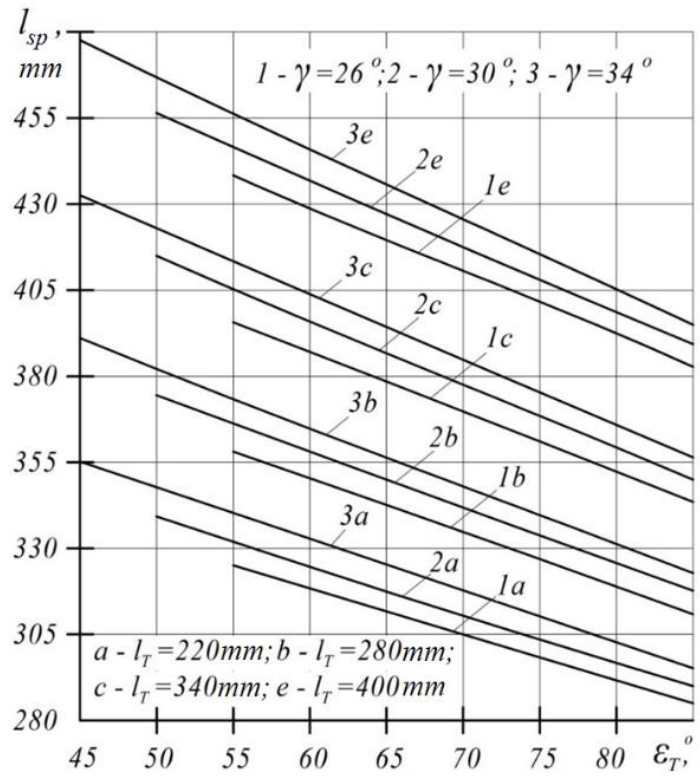

Figure 7. Graphic dependences $l_{s p}=f\left(\varepsilon_{T}\right)$ at different values of angles $\gamma=26^{\circ} ; \gamma=30^{\circ} ; \gamma=34^{\circ}$ and values of $l_{T}=220 \mathrm{~mm} ; 280 \mathrm{~mm} ; 340 \mathrm{~mm} ; 400 \mathrm{~mm}$ 
When analyzing the dependence (12), the value of $l_{p}$ was taken as a constant $l_{n}=300 \mathrm{~mm}$, because the design of the mechanism must provide for the choice of spring length using an adjustable rod.

Analysis of the graphical dependences shows that the angle of inclination $\gamma$ of the sides of the frame structure does not have a significant effect on the initial length of the compression spring $l_{s p}$. In this case, increasing the value of the angle $\gamma$ in the range from $26^{\circ}$ to $34^{\circ}$ brings to an increase in the range of change of the angle $\varepsilon_{T}$ from $55^{\circ} \ldots 85^{\circ}$ to $45^{\circ} \ldots 85^{\circ}$.

Thus, for $\varepsilon_{T}=55^{\circ}$, at which all graphical dependences begin or continue in the vertical direction, the change of the angle $\gamma$ in the range from $26^{\circ}$ to $34^{\circ}$ causes the increase in the value of $l_{s p}$ by $3.9 \ldots 4.3 \%$.

For $\varepsilon_{T}=85^{\circ}$ a change of angle $\gamma$ in the range from $26^{\circ}$ to $34^{\circ}$ brings to increase in the value of $l_{s p}$ by $3.1 \ldots 5.5 \%$.

At the same time, the value of spring $l_{T}$ significantly ettects the value of the spring length $l_{s p}$

Thus, for $\varepsilon_{T}=55^{\circ}$, an increase in the value of $l_{T}$ from $220 \mathrm{~mm}$ to $400 \mathrm{~mm}$ for the range of angles $\gamma=26^{\circ} \ldots 34^{\circ}$ causes an increase in the value of $l_{s p}$ by $1.34 \ldots 1.35$ times.

A similar increase in the value of $l_{s p}$ is also present for $\varepsilon_{T}=85^{\circ}$.

These analytical dependences are valid for the elements of tension of the ropes, which are located on the right side relative to the axis $O Y$.

To summarize the recommended parameters of the elements of ropes tension, consider their position on the left side relative to the axis $O Y$.

In the calculations, we take only the values of previously studied parameters that significantly impact the desired values.

To diagram the graphical dependences $\alpha=f\left(\varepsilon_{T}\right)$, considering the previous studies for the right side of the frame structure, we take the following values of the parameters: $\gamma=30^{\circ} ; l_{l e v}$ $=400 \mathrm{~mm} ; \mathrm{R}=45 \mathrm{~mm}$.

When conducting research, as in previous case, we take the value of $l_{f a}$ as: $l_{f a}=450$; 470; 490; 510; $530 \mathrm{~mm}$.

The difference is that in given above constant values of parameters the value of angle $\varepsilon_{T}$ which is less than angle $\varepsilon_{T}<\varepsilon_{n}$, is given step by step.

First, we set the dependence for finding angle $\varepsilon_{T}$

$$
\begin{gathered}
\sin \varepsilon_{T}=O^{\prime \prime} K^{\prime \prime} / l_{l e v} ; \\
O^{\prime \prime \prime} K^{\prime \prime}=l_{l e v} \sin \varepsilon_{T} .
\end{gathered}
$$

Dependence for calculation of distance $O^{\prime} C^{\prime}$

$$
O^{\prime} C^{\prime}=O^{\prime} K-O^{\prime \prime \prime} K^{\prime \prime}=\left(l_{f a} \cos \gamma-2 R\right)-l_{l e v} \sin \varepsilon_{T} .
$$

It is evident, that distance $O^{\prime} C^{\prime}$ is equal to the distance $33^{\prime}: O^{\prime} C^{\prime}=33^{\prime}$.

Then

$$
\operatorname{tg} \alpha=33^{\prime} / B K^{\prime \prime} \text {. }
$$

dependence for determining $B K^{\prime \prime}$ is similar to formula (8) for determining the value $B K^{\prime}$.

Substituting (14) and (8) into equation (15), we obtain

$$
\begin{array}{r}
\operatorname{tg} \alpha=\left(l_{f a} \cos \gamma-2 R-l_{l e v} \sin \varepsilon_{T}\right) /\left(l_{f a} \sin \gamma+l_{l e v} \cos \varepsilon_{T}\right), \\
\alpha=\operatorname{arctg}\left[\left(l_{f a} \cos \gamma-2 R-l_{l e v} \sin \varepsilon_{T}\right) /\left(l_{f a} \sin \gamma+l_{l e v} \cos \varepsilon_{T}\right)\right] .
\end{array}
$$


In Figure 8, graphical dependences $\alpha=f\left(\varepsilon_{T}\right)$ with various values $l_{f a}$ and $\varepsilon_{n}$ for $\gamma=30^{\circ}$ are given.

Their analysis shows that the trend of changing $\alpha=f\left(\varepsilon_{T}\right)$ is of opposite nature than the previous case and is described by linear dependence.

Herewith, increase of value of $l_{f a}$ in the given range does not cause significant increase of change of angle $\alpha$.

Thus, for $\varepsilon_{T}=20^{\circ}$ increase of value $l_{f a}$ from 450 to $530 \mathrm{~mm}$ brings to the increase of angle $\alpha$ by $32 \%$, and for $\varepsilon_{T}=50^{\circ}$ angle $\alpha$ changes from 0 to $6,8^{\circ}$, i.e. the range of its absolute value change is insignificant.

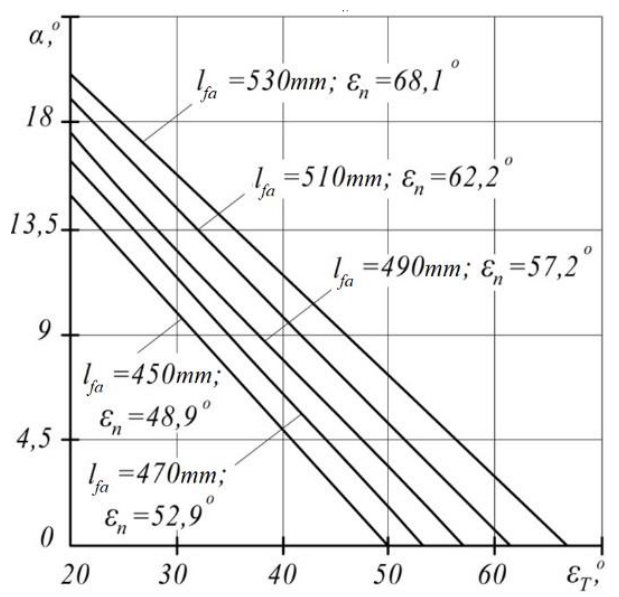

Figure 8. Graphic dependences $\alpha=f\left(\varepsilon_{T}\right)$ at different values of the angle $\varepsilon_{n}$, values of $l_{f a}$, for $\gamma=30^{\circ}$

Similarly to the previous case, we determine the impact of constructive parameters of the rope mechanism elements and also the areas of compressive springs fixation on their initial length $l_{s p}$ during the contact of rollers with the inner surfaces of ropes placed at different angles $\alpha$ to horizon.

Herewith, formulas (9)-(12) are valid for both cases when calculating the value of $l_{s p}$.

During analysis of dependence (12), for the left side of tension roller levers of the frame structure the value $l_{T}$ was given the range of discrete values due to the previous research, namely $l_{T}=(220 ; 280 ; 340 ; 400) \mathrm{mm}$. The values of the parameters were constant: $l_{n}=300 \mathrm{Mm} ; \gamma=30^{\circ}$.

The variation range of angle $\varepsilon_{T}$ was taken within the limits given in graphical dependences (Figure 8): $\varepsilon_{T}=20 \ldots 70^{\circ}$.

In Figure 9, the graphical dependences $l_{s p}=f\left(\varepsilon_{T}\right)$ for different values of $l_{T}$ are presented.

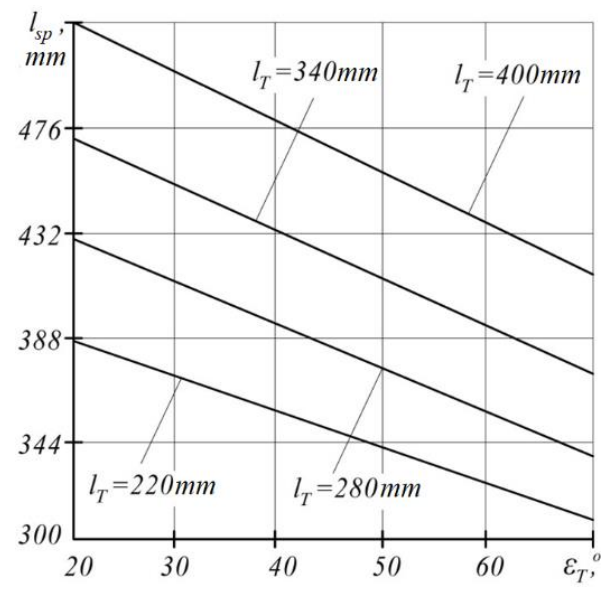

Figure 9. Graphic dependences $l_{s p}=f\left(\varepsilon_{T}\right)$ for $l_{n}=300 \mathrm{~mm} ; \gamma=30^{\circ}$ and different values $l_{T}=220 \mathrm{~mm} ; 280 \mathrm{~mm} ; 340 \mathrm{~mm} ; 400 \mathrm{~mm}$ 
Analysis of graphic dependencies shows that, as in the previous case, the increase of value $l_{T}$ brings to increase of value $l_{s p}$.

At the same time, the increase of angle $\varepsilon_{T}$ leads to the decrease of the spring length $l_{s p}$ in its initial state.

Thus, for the current angle $\varepsilon_{T}=20^{\circ}$ the increase of value $l_{T}$ in the range from $220 \mathrm{~mm}$ to $400 \mathrm{~mm}$ with the inclination angle of the sides of frame structure $\gamma=30^{\circ}$ causes the increase of value of $l_{s p}$ by 1.34 times. Similar increase of the initial length of the spring $l_{s p}$ occurs when the current angle is $\varepsilon_{T}=70^{\circ}$.

Conclusions. On the basis calculations and analysis of the research results, construction parameters of rope mechanism for its left and right sides relatively to axis OY are recommended.

The inclination angle of the sides $\gamma$ axis $O Y$ should be selected about $\gamma=30^{\circ}$ as such value is structurally rational and the deviation from it in different directions $+/-5^{\circ}$ does not significantly affect the desired values.

When choosing the parameters and position of roller levers and compression springs, it is necessary to focus on the layout of conveyor system of rope mechanism, namely the angle $\alpha$ of the ropes to the horizon, for which dependences are shown in Fig. 5 and 8.

When choosing the initial length of the spring $l_{s p}$, it is necessary to focus on the graphical dependences, which are shown in Figures 7 and 9, as well as to provide for the adjustment of its length by other mechanisms.

Based on the analysis, it can be stated that more accurate range of choice of structural parameters of the frame structure and springs that press the levers with rollers, as well as their relative position, taking into account the angle $\alpha$ of location of ropes to the horizon, can be given after force analysis.

\section{References}

1. Hevko R. B., Klendii M. B., Klendii O. M. (2016), Investigation of a transfer branch of a flexible screw conveyer, INMATEH: Agricultural Engineering, vol. 48, no.1, pp. 29-34.

2. Lyashuk O. L., Rogatynska O. R., Serilko D. L., (2015), Modelling of the vertical screw conveyer loading, INMATEH Agricultural Engineering, vol. 45, no.1, pp. 87-94.

3. Baranovsky V. M., Hevko R. B., Dzyura V. O., Klendii O. M., Klendii M. B., Romanovsky R. M., (2018), Justification of rational parameters of a pneumoconveyor screw feeder, INMATEH: Agricultural engineering, vol. 54, no. 1, pp. 15-24.

4. Hevko R. B., Zalutskyi S. Z., Hladyo Y. B. Tkachenko I. G. Lyashuk O. L., Pavlova O. M, Pohrishchuk B. V., Trokhaniak O. M., Dobizha N. V., (2019), Determination of interaction parameters and grain material flow motion on screw conveyor elastic section surface, INMATEH: Agricultural engineering. Bucharest, Romania, vol. 57, no. 1. pp. 123-134. DOI: https://doi.org/10.35633/INMATEH_57_13

5. Dovbush T, Khomuk N., Dovbush A., Rubinets N. (2017) Mathematical model of boundary crack propagation at bending of symmetric thin-walled flanks. Scientific Journal of TNTU (Tern.), vol. 86, no. 2, pp. 67-75.

6. Tson A., Baranovskyi V., Lyashuk O., Dovbush T. (2018) Experimental researches of parameters technological process of the improved beets tops purifier. Scientific Journal of TNTU (Tern.), vol. 92, no. 4, pp. 60-67. DOI: https://doi.org/10.33108/visnyk_tntu2018.04.060

7. Hevko R. B., Yazlyuk B. O., Liubin M. V., Tokarchuk O. A., Klendii O. M., Pankiv V. R., (2017), Feasibility study of mixture transportation and stirring process in continuous-flow conveyors, INMATEH: Agricultural Engineering, vol. 51, no. 1, pp. 49-59.

8. Hevko R. B., Liubin M. V., Tokarchuk O. A., Lyashuk O. L., Pohrishchuk B. V., Klendii O. M., (2018), Determination of the parameters of transporting and mixing feed mixtures along the curvilinear paths of tubular conveyors, INMATEH: Agricultural Engineering, vol. 55, no. 2, pp. 97-104.

9. Lyashuk O., Vovk Y., Sokil B., Klendii V., Ivasechko R., Dovbush T. Mathematical model of a dynamic process of transporting a bulk material by means of a tube scraping conveyor Agricultural Engineering International: CIGR Journal, Volume 21, Issue 1, 2019, pp. 74-81.

10. Mel'nychuk S. L., Hevko B. M., Diachun A. Y., Dzyura V. O., Skyba O. P., (2017), Investigation of the dynamics of unloading the sapropel from a bucket of a cable installation, INMATEH: Agricultural Engineering, vol. 52, no. 2, pp. 55-61. 
11. Lyashuk, O. L., Kolesnik, O. A., Melnichuk, S. L. Teoretichne doslIdzhennya pIdvIsnih mehanIzmIv pIdnImalno-transportnih lebIdok. NaukovI notatki. Vip. 53. 2016. LNTU. Lutsk. P. 97-102.

12. Gevko R. B., Nikeruy Yu. S. Eksperimentalna ustanovka ta metodika provedennya doslIdzhen kanatnogo mehanIzmu dlya zavantazhennya malih skladskih primIschen yablukami u tarI. NaukovI notatki. Vip. 67. LNTU. 2019. Lutsk. P. 29-33.

13. Gevko R. B., Nikeruy Yu. S., Dovbush T. A. Rezultati eksperimentalnih doslIdzhen kanatnogo mehanIzmu dlya zavantazhennya malih skladskih primIschen ovochami I fruktami $u$ tarI. SIlskogospodarskI mashini. Vip. 45. 2020. LNTU. Lutsk. P. 45-56.

14. Rogatinskiy R. M. Kanatniy mehanIzm zavantazhennya skladskogo primIschennya. Patent UkraYini na korisnu model № 125377 MPK B 65 G 7/08, 25/00 / R. M. Rogatinskiy, Yu. S. Nikeruy, R. B. Gevko, I. G. Tkachenko. Zayavka № u201711503. Zayavl. 24.11.2017. Opubl. 10.05.2018. Byul. № 9.

15. Nikeruy Yu. S. Kanatniy mehanIzm dlya zavantazhennya skladskogo primIschennya. Patent UkraYini na korisnu model № 130576 MPK B 65 G 7/00 / Yu. S. Nikeruy, R. B. Gevko, I. G. Tkachenko, B. V. PogrIschuk, N. V. DobIzha. Zayavka № u201807507. Zayavl. 04.07.2018. Opubl. 10.12.2018. Byul. № 23.

\section{Список використаної літератури}

1. Hevko R. B., Klendii M. B., Klendii O. M. (2016), Investigation of a transfer branch of a flexible screw conveyer, INMATEH: Agricultural Engineering, vol. 48, no. 1, pp. 29-34.

2. Lyashuk O. L., Rogatynska O. R., Serilko D. L., (2015), Modelling of the vertical screw conveyer loading, INMATEH Agricultural Engineering, vol. 45, no. 1, pp. 87-94.

3. Baranovsky V. M., Hevko R. B., Dzyura V. O., Klendii O. M., Klendii M. B., Romanovsky R. M., (2018), Justification of rational parameters of a pneumoconveyor screw feeder, INMATEH: Agricultural engineering, vol. 54, no. 1, pp. 15-24.

4. Hevko R. B., Zalutskyi S. Z., Hladyo Y. B. Tkachenko I. G. Lyashuk O. L., Pavlova O. M, Pohrishchuk B. V., Trokhaniak O. M., Dobizha N. V., (2019), Determination of interaction parameters and grain material flow motion on screw conveyor elastic section surface, INMATEH: Agricultural engineering. Bucharest, Romania, vol. 57, no. 1, pp. 123-134. DOI: https://doi.org/10.35633/INMATEH_57_13

5. Dovbush T, Khomuk N., Dovbush A., Rubinets N. (2017) Mathematical model of boundary crack propagation at bending of symmetric thin-walled flanks. Scientific Journal of TNTU (Tern.), vol. 86, no. 2 , pp. $67-75$.

6. Tson A., Baranovskyi V., Lyashuk O., Dovbush T. (2018) Experimental researches of parameters technological process of the improved beets tops purifier. Scientific Journal of TNTU (Tern.), vol. 92, no. 4, pp. 60-67. DOI: https://doi.org/10.33108/visnyk_tntu2018.04.060

7. Hevko R. B., Yazlyuk B. O., Liubin M. V., Tokarchuk O. A., Klendii O. M., Pankiv V. R., (2017), Feasibility study of mixture transportation and stirring process in continuous-flow conveyors, INMATEH: Agricultural Engineering, vol. 51, no. 1, pp. 49-59.

8. Hevko R. B., Liubin M. V., Tokarchuk O. A., Lyashuk O. L., Pohrishchuk B. V., Klendii O. M., (2018), Determination of the parameters of transporting and mixing feed mixtures along the curvilinear paths of tubular conveyors, INMATEH: Agricultural Engineering, vol. 55, no. 2, pp. 97-104.

9. Lyashuk O., Vovk Y., Sokil B., Klendii V., Ivasechko R., Dovbush T. Mathematical model of a dynamic process of transporting a bulk material by means of a tube scraping conveyor Agricultural Engineering International: CIGR Journal, Volume 21, Issue 1, 2019, pp. 74-81.

10. Mel'nychuk S. L., Hevko B. M., Diachun A. Y., Dzyura V. O., Skyba O. P., (2017), Investigation of the dynamics of unloading the sapropel from a bucket of a cable installation, INMATEH: Agricultural Engineering, vol. 52, no. 2, pp. 55-61.

11. Ляшук, О. Л., Колесник, О. А., Мельничук, С. Л. Теоретичне дослідження підвісних механізмів піднімально-транспортних лебідок. Наукові нотатки. Вип. 53. 2016. ЛНТУ. Луцьк. С. 97-102.

12. Гевко Р. Б., Никеруй Ю. С. Експериментальна установка та методика проведення досліджень канатного механізму для завантаження малих складських приміщень яблуками у тарі. Наукові нотатки. Вип. 67. ЛНТУ. 2019. Луцьк. С. 29-33.

13. Гевко Р. Б., Никеруй Ю. С., Довбуш Т. А. Результати експериментальних досліджень канатного механізму для завантаження малих складських приміщень овочами і фруктами у тарі. Сільськогосподарські машини. Вип. 45. 2020. ЛНТУ. Луцьк. С. 45-56.

14. Рогатинський Р. М. Канатний механізм завантаження складського приміщення. Патент України на корисну модель № 125377 МПК В 65 G 7/08, 25/00 / Р. М. Рогатинський, Ю. С. Никеруй, Р. Б. Гевко, І. Г. Ткаченко. Заявка № u201711503. Заявл. 24.11.2017. Опубл. 10.05.2018. Бюл. № 9. 
15. Никеруй Ю. С. Канатний механізм для завантаження складського приміщення. Патент України на корисну модель № 130576 МПК В 65 G 7/00 / Ю. С. Никеруй, Р. Б. Гевко, І. Г. Ткаченко, Б. В. Погріщук, Н. В. Добіжа. Заявка № u201807507. Заявл. 04.07.2018. Опубл. 10.12.2018.; Бюл. № 23.

\title{
УДК 621.867.42
}

\section{ОБГРУНТУВАННЯ КОНСТРУКТИВНИХ ПАРАМЕТРІВ ЕЛЕМЕНТІВ РАМНОЇ КОНСТРУКЦІЇ ТРАНСПОРТНОЇ СИСТЕМИ КАНАТНОГО МЕХАНІЗМУ ДЛЯ ЗАВАНТАЖЕННЯ ШТУЧНИМИ ВАНТАЖАМИ МАЛИХ СКЛАДСЬКИХ ПРИМІЩЕНЬ}

\author{
Роман Гевко; Юрій Никеруй; Тарас Довбуш; Василь Олексюк
}

\author{
Тернопільський нащіональний технічний університет імені Івана Пулюя, \\ Тернопіль, Україна
}

\begin{abstract}
Резюме. Технологічні процеси завантаження штучними вантажами малих складських приміщень, такими як, яблука, картопля або іншими фруктами чи овочами потребують забезпечення високої продуктивності та мінімізащії ступеня їх пошкодження в процесі переміщення до зони вивантаження, які не повинні перевищувати допустимі норми або бути взагалі відсутніми. В роботі наведено теоретичне обтрунтування меж рачіональних конструктивних параметрів рамної конструкиії для розміщення штучних вантажів, а також підпружинених важелів з роликами та їх розташування, які взаємодіють з внутрішньою поверхнею направляючих канатів розробленої транспортної системи. Встановлені межі раціональних кутових положень важелів та їх пружин підтискання до похилих боковин для правої та лівої сторін рухомих елементів рамної конструкиії відносно центральної вертикальної осі, а також кута розташування направляючих канатів до горизонту. При виборі конструктивних параметрів і положення розташування важелів з роликами та пружин стискання, в першу чергу, необхідно орієнтуватися на компонувальну схему транспортної системи канатного механізму, а саме кута а розташування канатів до горизонту. При виборі початкової довжини пружини $l_{s p}$ необхідно орієнтуватися на отримані графічні залежності, а також передбачити регулювання ії довжини за допомогою інших механізмів. Кут нахилу боковин $\gamma$ до осі ОҮ варто вибирати близьким $\gamma=30^{\circ}$, оскільки його таке значення є конструктивно рачіональним, а відхилення від нього в різні сторони в межах $+\backslash-5^{\circ}$ суттєво не впливає на шукані величини. На основі отриманих результатів розрахунків і рекомендацій стосовно вибору параметрів запропонованих технічних рімень виготовлено канатний механізм для завантаження малих складських приміщень штучними вантажами та проведено попередні експериментальні дослідження.
\end{abstract}

Ключові слова: канатний механізм, конструктивні параметри, підтискні важелі, опорні ролики, кути провертання. 